\title{
PENGARUH MOTIVASI KERJA, IKLIM ORGANISASI TERHADAP KOMITMEN ORGANISASI DAN KINERJA DOSEN PENDIDIKAN GURU PENDIDIKAN ANAK USIA DINI IKIP PGRI JEMBER
}

\section{THE EFFECT OF WORK MOTIVATION, ORGANIZATIONAL CLIMATE ON ORGANIZATIONAL AND PERFORMANCE COMMITMENTS OF EDUCATION TEACHERS OF AGE CHILDREN EDUCATION TEACHERS IN IKIP PGRI JEMBER}

\author{
Chairul Hanafi dan Abadi Sanosra \\ Program Magster Manajemen Universitas Muhamamdiyah Jember \\ Email: abadi@unmuhjember.ac.id
}

\begin{abstract}
ABSTRAK
Penelitian ini bertujuan untuk menguji pengaruh Motivasi Kerja dan Iklim Organisasi terhadap Kinerja dengan Komitmen Organisasi sebagai variabel intervening pada program studi pendidikan guru pendidikan anak usia dini IKIP PGRI Jember baik pengaruh langsung maupun pengaruh tidak langsung guna mengetahui tingkat Kinerja yang dimiliki oleh dosen pada lingkungan kerja Pendidikan Guru Pendidikan Anak Usia Dini IKIP PGRI Jember. Dimana seluruh populasi dalam penielitian ini dijadikan sebagai objek penelitian, hal ini dilakukan karena populasi dari penelitian ini populasinya kurang dari 100 responden. Metode yang digunakan dalam penelitian ini adalah dengan cara memberikan kuesioner kepada responden, dimana kuesioner tersebut berisikan pertanyaan yang berkaitan dengan variabel-variabel penelitian. Teknik analisis data yang digunakan adalah dengan path analysis yang dijalankan dengan program SPSS16 for Windows. Path analysis digunakan untuk mengetahui pengaruh variabel independen terhadap variabel dependen. Hasil analisis menunjukkan bahwa variabel Motivasi tidak berpengaruh signifikan terhadap Komitmen Organisasibaik secara langsung maupun secara tidak langsung, sedangkan Iklim Organisasi secara langsung berpengaruh signifikan terhadap Komitmen Organisasi, tetapi tidak berpengaruh signifikan jika sebagai variabel intervening, sedangkan variabel Komitmen Organisasi berpengaruh signifikan terhadap Kinerja.
\end{abstract}

Kata Kunci: Motivasi Kerja, Iklim Organisasi, Kinerja, Komitmen Organisasi.

\begin{abstract}
This research aims to test the influenve of Organizational Climate and Work Motivation on performence with the Organizational Commitment as an intervening variable in the study programs of teacher education early childhood education IKIP PGRI Jember. Where is the rest of the population in this study was used as the object of research, this is done because the population is less than 100 respondents. The methods is by giving questionnaires to respondents, where the questionnaire contains question related to the research variabel. Data analysis technique used is with path analysis performed with the program SPSS for windows. Path analysis used to influence the dependent variable against the independent variable. The results of the analysis show that variabel has no effect significant motivation against the organizational commitment either directly or indirectly, while the climate organizational directly influlential significant against organizational commitment, but not significant effect if the intervening variable, whereas the variable organizational commitment significantly to performence.
\end{abstract}

Keywords: Organizational Climate, Motivation, Performance, Organizational Commitment. 


\section{PENDAHULUAN}

Organisasi adalah suatu kumpulan individu yang memiliki tugas bersama untuk mencapai tujuan tertentu (De Vito, 1997:337 ). Semuanya diatur dalam AD/ART organisasi tersebut. Tiap individu dalam organisasi memiliki peran dan tugas yang berbeda - beda untuk mencapai tujuan yang telah ditetapkan. Semakin besar organisasi maka semakin kompleks permasalahan dalam organisasi tersebut. Akan tetapi hal tersebut dapat diatasi jika tercipta iklim organisasai yang memadai. Iklim organisasi bersifat abstrak, dan bisa dirasakan dari kepercayaan atasan terhadap bawahan, keterbukaan, kedisplinan, tolong menolong serta didukung oleh suasana dan kondisi yang kondusif. Dengan berbagai individu yang mempunyai kepribadian yang berbeda seharusnya dapat mendukung untuk tercapainya tujuan organisasi. SDM yang memadai merupakan hal yang mutlak untuk tercapai atau tidaknya tujuan suatu organisasi.

Menurut Mayer (1989) dalam Sanusi (2012:6) menyebutkan organisasi yang efektif hanya akan ada jika suatu organisasi memiliki sumber daya manusia yang berkomitmen terhadap organisasi. Baik berupa pemikiran - pemikiran yang cemerlang agar organisasi lebih cepat mencapai tujuan yang telah dirumuskan. Pegawai yang memiliki komitmen tinggi sangat berpengaruh terhadap kinerja organisasi. Sumber daya manusia yang berkomitmen tinggi memiliki produktifitas dan tanggung jawab yang tinggi untuk berkontribusi dalam pencapaian tujuan organisasi ( Mowday, Porter dan Steer, 1982).

Keberhasilan suatu perguruan tinggi untuk mencetak tenaga yang kompeten dibidangnya ditentukan oleh tenaga pendidik di perguruan tinggi tersebut. Agar proses belajar mengajar di perguruan tinggi berjalan dengan lancar dan sesuai dengan target yang diharapkan maka diharapkan staf pengajar mempunyai hubungan atau keterikatan psikologis dengan organisasi dalam hal ini adalah perguruan tinggi. Keterikatan antara staf pengajar dengan perguruan tinggi disebut dengan komitmen organisasi. Menurut Robbins (1994: 8) komitmen organisasional didefinisikan sebagai suatu keadaan dimana seorang karyawan memihak pada suatu organisasi tertentu serta berniat memelihara keanggotaannya dalam organisasi tersebut.

Komunikasi didalam organisasi tidak hanya terjadi secara instruktif dari atasan terhadap bawan tetapi juga bisa terjadi secara horizontal, vertikal maupun diagonal. Jenis komunikasi ini akan memperpendek bahkan terkadang bersifat tidak formal. Iklim 
komunikasi yang sehat berarti ada saling kepercayaan dan saling mendukung antara anggota organisasi. Dengan adanya kelancaran komunikasi yang baik maka akan ada pengutan komunikasi antar anggota komunikasi. Dengan adanya komunikasi yang baik maka akan menjadikan motivasi agar bekerja lebih baik.

Menurut Maharjan (2012), kinerja adalah suatu hasil yang dicapai karena termotivasi dengan pekerjaan dan puas dengan pekerjaan yang mereka lakukan. Tiap individu cenderung akan dihadapkan pada hal-hal yang mungkin tidak diduga sebelumnya di dalam proses mencapai kebutuhan yang diinginkan sehingga melalui bekerja dan pertumbuhan pengalaman, seseorang akan memperoleh kemajuan dalam hidupnya. Kinerja dalam hal ini menunjukkan hasil kerja yang dicapai seseorang setelah melaksanakan tugas pekerjaan yang dibebankan oleh organisasi, sedangkan ukuran baik tidaknya hasil kerja dapat dilihat dari mutu atau kualitas yang dicapai pegawai sesuai dengan tuntutan organisasi. Al-Ahmadi (2009) melakukan studi terhadap 923 perawat pada rumah sakit di Riyadh, Arab Saudi mengenai hubungan antara kinerja karyawan dengan kepuasan kerja dan komitmen organisasional. Chen et al. (2007) mengadakan penelitian mengenai praktek sumber daya manusia, kekuatan sumberdaya manusia, komitmen afektif, dan kinerja karyawan. Dampak komitmen pada kinerja karyawan tidak signifikan secara relatif.

Tugas utama bagi seorang dosen adalah menjalankan Tri Dharma Perguruan tinggi. Tri Dharma tersebut adalah pelaksanaan proses belajar mengajar, pengabdian pada masyarakat, dan penelitian. Yang tergolong dalam proses belajar diantaranya adalah: pengumpulan bahan ajar, penyelenggaraan proses belajar mengajar, penyerahan Rancangan Proses Pembelajaran, dan lain-lain. Pada lingkungan kerja Pendidikan Guru Pendidikan anak Usia Dini pada lingkungan kerja IKIP PGRI Jember telah terjadi penurunan kinerja dosen. Hal tersebut dapat dilihat dari tabel berikut:

Tabel 1. Data penyelesaian Tugas Tri Dharma Dosen Pendidikan Guru Pendidikan Anak Usia Dini IKIP PGRI Jember

\begin{tabular}{|l|l|c|c|c|}
\hline No & Tahun & Jumlah dosen NIDN & Memenuhi Tri Dharma & Persentase \\
\hline 1 & 2014 & 20 & 18 & 90 \\
\hline 2 & 2015 & 83 & 60 & 72,29 \\
\hline 3 & 2016 & 73 & 50 & 68,50 \\
\hline
\end{tabular}

Sumber: data statistik pada IKIP PGRI Jember 
Dari fenomena diatas dapat dilihat bahwa terjadi penurunan kinerja dosen dari tahun ketahun. Berdasarkan fenomena tersebut peneliti mencoba memberikan asumsi bahwa yang menjadi dasar penurunan kinerja tersebut adalah: Motivasi Kerja, Iklim Organisasi, Komitmen Organisasi. Faktor-faktor tersebut kemudian diuji kebenarannya dengan menyebarkan kuesioner guna mengetahui pengaruh antar variabel dengan berlandaskan teori, dan empiris.

\section{TINJAUAN PUSTAKA}

\section{Motivasi Kerja}

Banyak teori motivasi yang dikemukakan oleh para ahli, salah satunya adalah Teori Maslow menyebutkan bahwa motivasi terbentuk karena 5 hierarki kebutuhan (Maslow, 1994):

1. Kebutuhan fisiologis (physiological needs) yaitu kebutuhan yang diperlukan untuk mempertahankan kelangsungan hidup seseorang, seperti makan, minum, udara, perumahan dan lainnya.

2. Kebutuhan keselamatan dan keamanan (safety and security need) yaitu kebutuhan keamanan dari ancaman yakni merasa aman dari ancaman kecelakaan dalam melakukan pekerjaan.

3. Kebutuhan rasa memiliki (social need) yaitu kebutuhan akan teman, cinta dan memiliki. Sosial need di dalam organisasi dapat berupa keompok kerja (team work) baik secara formal maupun informal.

4. Kebutuhan akan harga diri (esteem need or status needs) yaitu kebutuhan akan penghargaan diri, pengakuan serta penghargaan prestise dari karyawan dan masyarakat lingkungan.

5. Kebutuhan akan perwujudan diri (self actualization) adalah kebutuhan akan aktualisasi diri dengan menggunaka kecakapan, kemampuan, keterampilan dan potensi optimal untuk mencapai prestasi kerja yang sangat memuaskan atau luar biasa yang sulit dicapai orang lain.

Azhad, dkk (2015) meyatakan bahwa motivasi adalah dorongan yang membeuat seseorang dapat melakukan tugasnya dengan baik. Gomes (2003:171) mendifinisikan motivasi sebagai perilaku yang ditujukan pada sasaran. Motivasi berkaitan dengan tingkat usaha yang dilakukan oleh seseorang dalam mengejar suatu tujuan dan berkaitan erat dengan kepuasan pekerja dan performansi pekerjaan. 


\section{Iklim Organisasi}

Orang-orang yang menjadi anggota suatu organisasi hidup dalam lingkup organisasi dan berinteraksi membentuk sistem sosial yang dalam perkembangannya tidak lepas dari pengaruh lingkungan baik lingkungan eksternalnya maupun lingkungan internalnya. Artinya selain harus hidup dengan perubahan lingkungan yang terkadang susah diprediksi, anggota organisasi juga harus menghadapi perubahan yang ada dalam lingkungan organisasi tersebut. Organisasi selamanya unik seperti halnya sidik jari dan lapisan salju, masing-masing organisasi memiliki budaya, tradisi, dan metode tindakannya sendiri yang secara keseluruhan menciptakan iklimnya (Davis, 2001). Begitu uniknya yang membuat tiap organisasi mempunyai kondisi psikologis yang berbeda. Suatu organisasi cenderung menciptakan kondisi yang dinamis serta menarik bagi karyawannya. Sementara organisasi lain memberikan nuansa yang lamban dan tidak produktif. Beberapa organisasi bisa terlihat sibuk dan efisien, dan yang lain tampak santai, atau sebagian lainnya cukup manusiawi, tetapi sebagian lainnya justru terlihat kaku dan dingin. Nuansa psikologis inilah yang merefleksikan iklim dalam organisasi.

\section{Komitmen Organisasi}

Menurut Mathis dan Jackson (2006:98) memberikan definisi “Organizational Commitment is the degree to which employees believe in and accept organizational goals and desire to remain with the organization" yaitu komitmen organisasional adalah derajat yang mana karyawan percaya dan menerima tujuan - tujuan organisasi dan akan tetap tinggal atau tidak akan meninggalkan organisasi. Darwish A (2000) Komitmen organisasi didefinisikan sebagai perasaan kewajiban karyawan untuk tinggal dengan organisasi, perasaan ini dihasilkan dari tekanan internalisasi normatif yang diberikan pada seorang individu.

\section{Kinerja}

Arti kata kinerja berasal dari taka-kata job performance dan di sebut juga actual performance atau prestasi kerja atau prestasi sesungguhnya yang telah di capai oleh seseorang kariyawan. Moeherionto ( 2012: 69). Menurut oxfoord dictionary, kinerja (performance) merupakan suatu tindakan proses atau cara bertindak atau melakukan fungsi organisasi. 
Kinerja adalah suatu hasil kerja yang dicapai seorang dalam melaksanakan tugastugas yang dibebankan kepadanya yang didasarkan atas kecakapan, pengalaman dan kesungguhan serta waktu (Hasibuan, 2006).

\section{METODE PENELITIAN}

\section{Jenis Penelitian}

Berdasarkan latar belakang masalah dan rumusan masalah yang ada, karakteristik masalah yang diteliti dalam penelitian ini dapat diklasifikasikan sebagai explanatory research, yaitu metodologi penelitian yang menjelaskan hubungan suatu variable dengan variable lain dan menguji keterkaitan antara beberapa variable melalui pengujian hipotesis atau penelitian penjelasan (Singarimbun dan Effendi, 1995).

\section{Desain Penelitian}

Menurut Supranto (2001:237) desain penelitian pada dasarnya untuk menentukan metode apa saja yang akan dipergunakan dalam penelitian. Sedangkan Kerlingger (2004:483) mengungkapkan bahwa desain penelitian atau rancang bangun penelitian adalah rencana dan struktur (model/paradigma) penyeli dikan yang disusun sedemikian rupa untuk memperoleh jawaban atas pertanyaan- pertanyaan penelitian.

\section{Uji Validitas}

Uji validitas digunakan untuk mengetahui sah atau valid tidaknya suatu kuesioner, suatu kuesioner dinyatakan valid jika pertanyaan pada kuesioner mampu untuk mengungkapkan sesuatu yang akan diukur oleh kuesioner tersebut (Ghozali, 2013:52). Mengukur validitas dapat dilakukan dengan cara melakukan korelasi bivariate antara masing-masing skor indikator dengan total skor konstruk atau variabel. Apabila korelasi masing-masing skor pertanyaan dengan skor total menunjukkan hasil yang signifikan atau kurang dari $\alpha=0,05$ maka kuisioner dikatakan valid. Penghitungan menggunakan perangkat lunak IBM SPSS versi 16.00 .

\section{Uji Reliabilitas}

Uji reliabilitas menunjukkan pada satu pengertian bahwa suatu instrument cukup dipercaya untuk digunakan sebagai alat pengumpul data karena instrument tersebut sudah baik. Sebuah instrument haruslah reliable, yaitu bahwa suatu instrument cukup baik sehingga mampu mengungkap data yang bisa dipercaya (Arikunto, 2006). Uji reliabilitas menggunakan crobach's alpha, suatu instrument dikatakan reliable jika crobach's alpha lebih besar dari 0,60 (Ghozali, 2005). Metode yang digunakan untuk menguji keadaan 
alat ukur dalam penelitian ini adalah menggunakan Metode Cronbach (Alpa / Reliability Analysis), perhitungan dari nilai reliabilitas menggunakan perangkat lunak IBM SPSS versi 16.00 .

\section{Analisis Jalur (path analysis)}

Tehnik analisis yang digunakan untuk menganalisis data penelitian adalah analisis jalur atau analisis lintas / sidik lintas (path analysis). Menurut Imam Ghozali (2011:134) dalam pengujian model dengan path analysis terdapat lima langkah yang harus ditempuh, yaitu merancang model berdasarkan konsep dan teori, menguji asumsi yang melandasi path analysis, pendugaan parameter atau perhitungan path coefficient, pengujian validitas model dan interpretasi hasil analisis.

Model dalam penelitian ini dapat dinyatakan dalam bentuk persamaan, sehingga membentuk persamaan simultan atau model structural berikut. (Ghozali,2011:135):

$$
\begin{aligned}
& Z=a 2+b 1 X 1+b 2 X 2+e 1(\text { persamaan substruktur } 1) \\
& Y=a 3+b 3 X 1+b 4 X 2+b 5 Z+e 2(\text { persamaan substruktur } 2)
\end{aligned}
$$

\section{HASIL DAN PEMBAHASAN}

\section{Analisis Jalur (path analysis)}

Ghozali (2013:249) menyatakan bahwa untuk menguji pengaruh variabel intervening digunakan metode analisis jalur (Path Analysis). Analisis jalur merupakan perluasan dari analisis regresi linear berganda, atau analisis jalur adalah penggunaan analisis regresi untuk menaksir hubungan kausalitas antar variabel (model causal) yang telah ditetapkan sebelumnya.

Tabel 2.Koefisien Jalur

\section{Model 1}

\begin{tabular}{ccc}
\hline No & Variabel & Koefisien \\
\hline 1 & Konstanta & 10.478 \\
2 & Motivasi Kerja & 0.066 \\
3 & Iklim Organisasi & 0.287 \\
\hline
\end{tabular}

Sumber : Data Diolah.

Persamaan model 1 yang terbentuk berdasarkan Tabel 2. adalah sebagai berikut:

$$
Z=10.478+0.066 X 1+0.287 X 2
$$


Tabel 3. Koefisien Jalur Model 2

\begin{tabular}{ccc}
\hline No & Variabel & Koefisien \\
\hline 1 & Konstanta & 1.324 \\
2 & Motivasi Kerja & 0.153 \\
3 & Iklim Organisasi & 0.235 \\
4 & Komitmen Organisasi & 0.425 \\
\hline
\end{tabular}

Sumber: Data Diolah.

Persamaan model 2 yang terbentuk berdasarkan Tabel 3. adalah sebagai berikut:

$\mathrm{Y}=1.324+0.153 \mathrm{X} 1+0.235 \mathrm{X} 2+0.425 \mathrm{Z}$

\section{Analisis Koefisien Determinasi}

Koefisien determinasi merupakan besaran yang menunjukkan besarnya variasi variabel dependen yang dapat dijelaskan oleh variabel independennya. Dengan kata lain, koefisien determinasi ini digunakan untuk mengukur seberapa jauh variabel-variabel bebas dalam menerangkan variabel terikatnya.

Tabel 4.H sil Koefisien Determinasi

\begin{tabular}{cc}
\hline Model & $\begin{array}{c}\text { Adjusted } R \\
\text { Square }\end{array}$ \\
\hline 1 & 0.082 \\
2 & 0.292 \\
\hline
\end{tabular}

Sumber: Data Diolah.

Nilai Adjusted $R$ Square pada model 1 sebesar 0.082menunjukkan bahwa 8.2\% Komitmen Organisasi dosen IKIP PGRI Jember dipengaruhi oleh Motivasi Kerja dan Iklim Kerja, sedangkan sisanya $91.8 \%$ dipengaruhi oleh variabel lain diluar model atau persamaan. Nilai Adjusted $R$ Square pada model 2 sebesar 0.292 menunjukkan bahwa Motivasi Kerja dan Iklim kerja dapat mempengaruhi Kinerja dosen sebesar 29.2\%, sedangkan sisanya $60.8 \%$ dipengaruhi oleh variabel lain diluar model atau persamaan.

\section{Pembahasan}

\section{Pengaruh Motivasi Kerja terhadap Komitmen Organisasi}

Motivasi adalah sikap yang mempengaruhi individu untuk mencapai tujuan yang diinginkan. Sikap tersebut menjadi pendorong individu tersebut untuk melakukan sesuatu dalam mencapai tujuannya. Dorongan tersebut terdiri dari dua komponen, yaitu: arah 
perilaku kerja (kerja untuk mencapai tujuan), dan kekuatan perilaku (sebagai kuat usaha individu dalam bekerja).

Hipotesis pertama menunjukkan Motivasi memiliki nilai signifikansi sebesar 0,041 lebih besar dari 0,05, sehingga hipotesis pertama yang menyatakan Motivasi berpengaruh positif terhadap Komitmen Organisasi ditolak. Hal ini menunjukkan bahwa pada lingkungan kerja Pendidikan Guru Pendidikan Anak Usia Dini IKIP PGRI Jember Komitmen Organisasi lebih banyak dipengaruhi oleh faktor - faktor lain dari pada Motivasi Kerja. Hal ini tidak mendukung penelitian yang dilakukan oleh Tania dan Sutanto (2013) dan Elisabeth ,dkk (2014) yang memperoleh hasil bahwa motivasi kerja mempunyai pengaruh terhadap komitmen organisasi yang dimiliki oleh karyawan.

\section{Pengaruh Iklim Organisasi Terhadap Komitmen Organisasi}

George Litwin dan Robert Stringer dalam Alavi dan Jahandari (2005: 250) mendefinisikan iklim organisasi adalah persepsi orang dalam organisasi dimana ia bekerja dan pandangan atau perasaannya tentang dimensi-dimensi seperti kebebasan, struktur organisasi, upah dan gaji, kehati-hatian dan ketulusan hati dan dukungan terhadap organisasi. Pengaruh iklim organisasi terhadap Komitmen Organisasi diperoleh hasil signifikansi sebesar 0,032 . Hasil perhitungan tersebut lebih kecil dari $P$-Value yaitu 0,05 sehingga hipotesis yang kedua yang berbunyi Iklim Organisasi berpengaruh terhadap Komitmen Organisasi diterima.dari pengujian statistik ini membuktikan bahwa jika Iklim Organisasi di lingkungan kerja Pendidikan Guru Pendidikan Anak Usia Dini IKIP PGRI Jember semakin baik maka akan meningkatkan Komitmen Organisasi dari dosen terhadap KIP PGRI Jember. Hal ini mendukungpenelitian sebelumnya yang telah dilakukan oleh Kurniawati (2011) mengenai pengaruh Iklim Organisasi terhadap Komitmen Organisasi, didapatkan hasil bahwa iklim organisasi berpengaruh terhadap komitmen organisasi.

\section{Pengaruh Komitmen Organisasi Terhadap Kinerja}

Komitmen organisasional merupakan prediktor yang signifikan terhadap intensi karyawan untuk keluar dari organisasi dan bisa dijadikan solusi yang efektif untuk mengatasi turnover karyawan (Sulu et al., 2010). Hasil statistik dari pengujian pengaruh Komitmen Organisasi terhadap Kinerja diperoleh hasil signifikansi sebesar 0,002 hasil tersebut lebih kecil dari P-Value $(0,005)$ artinya Komitmen Organisasi mempunyai pengaruh terhadap Kinerja. Hal ini menunjukkan jika Komitmen Organisasinya membaik 
maka Kinerja Dosen di lingkungan kerja Pendidikan Guru Pendidikan Anak Usia Dini IKIP PGRI Jember juga akan membaik. Hasil tersebut mendukung penelitian yang pernah dilakukan oleh Primata yang dilakukan pada tahun 2014 menyimpulkan bahwa komitmen organisasi mempunyai pengaruh terhadap kinerja karyawan.

\section{Pengaruh Motivasi Kerja Terhadap Kinerja}

Motivasi dapat diartikan sebagai dorongan dan keinginan serta upaya yang muncul dari diri seorang individu untuk melakukan suatu hal. Yuwono dkk. (2005) dalam Juniantara (2015:16) mendefinisikan motivasi sebagai suatu proses yang membangkitkan, mengarahkan dan menjaga atau memelihara perilaku manusia agar terarah pada tujuan. Untuk lebih meningkatkan peformance dan sikap lebih positif, sebaiknya menggunakan dan terpusat pada faktor faktor motivator. Pengaruh Motivasi Kerja terhadap Kinerja yang dilakukan perhitungan secara statistik pada lingkungan kerja Pendidikan Guru Pendidikan Anak Usia Dini IKIP PGRI Jember diperoleh hasil signifikansi sebesar 0,061 lebih besar dari nilai P-Value yaitu 0,05. Hal ini menunjukkan bahwa Motivasi Kerja tidak mempunyai pengaruh yang baik terhadap peningkatan Kinerja. Dengan kata lain bahwa Kinerja dosen Pendidikan Guru Pendidikan Anak Usia Dini IKIP PGRI Jember dapat ditingkatkan dari faktor lain selain peningkatan Motivasi. Hal ini tidak mendukung penelitian yang dilakukan oleh Keran pada tahun 2012 ditemukan bahwa motivasi kerja pada karyawan nantinya akan mempengaruhi kinerja, semakin tinggi motivasi karyawan dalam bekerja maka akan semakin tiggi pula kinerja karyawan tersebut dan berlaku pula sebaliknya yaitu jika motivasi yang dimiliki karyawan cenderung rendah maka akan ada kecenderungan kinerja karyawan tersebut akan rendah juga. Serta penelitian yang dilakukan oleh Juniantara tahun 2015 diperoleh bahwa motivasi karyawan berpengaruh signifikan dan positif terhadap kinerja karyawan.

\section{Pengaruh Iklim Organisasi Terhadap Kinerja}

Hasil hitung statistik yang dilakukan untuk mengukur pengaruh Iklim Organisai terhadap Kinerja diperoleh hasil signifikansi sebesar 0,095 hasil tersebut lebih besar $P$ Value yaitu 0,05. Artinya Iklim Organsasi tidak memiliki pengaruh yang cukup besar terhadap peningkatan Kinerja dosen dilingkungan kerja Pendidikan Guru Pendidikan Anak Usia Dini IKP PGRI Jember. hal tersebut tidak mendukung penelitian yang dilakukan oleh Affandi (2002), Akbar (2009) dan Henaldy (2009) yang menemukan adanya pengaruh positif antara iklim organisasi terhadap kinerja karyawan. 


\section{Pengaruh Tidak Langsung Motivasi Kerja Terhadap Kinerja}

Pengaruh tidak langsung Motivasi Kerja terhadap Kinerja dengan variabel perantara yaitu Komitmen Organiasasi yang dilakukan dengan cara perhitungan dengan sobel test diperoleh nilai cut point sebesar 0,082 leboh kecil dari 1,96 yang artinya Motivasi Kerja secara tidak langsung tidak dapat mempengaruhi Kinerja dengan signifikan. Jadi Motivasi Kerja lebih banyak dipengaruhi oleh faktor lain. Hasil perhitungan sobel test tersebut tidak mendukung penelitian yang dilakukan oleh Jatmiko (2015) motivasi berpengaruh signifikan secara simultan dan parsial terhadap kinerja, yang berarti semakin tinggi motivasi yang diterima, maka semakin tinggi pula kinerja pegawai tersebut.

\section{Pengaruh Tidak Langsung Iklim Organisasi Terhadap Kinerja}

Pengaruh tidak langsung Iklim Organisasi terhadap Kinerja dengan variabel perantara yaitu Komitmen Organiasasi yang dilakukan dengan cara perhitungan dengan sobel test diperoleh nilai cut point sebesar 1,81 lebih kecil daari 1,96 yang artinya Iklim Organisasi secara tidak langsung tidak dapat mempengaruhi Kinerja dengan signifikan. Jadi Iklim Organiasasi lebih banyak dipengaruhi oleh faktor lain. Hasil perhitungan sobel test tersebut tidak mendukung penelitian yang dilakukan oleh Benny Roesly (2012) yang diperoleh hasil bahwa Iklim Organisasi berpengaruh terhadap Kinerja.

\section{KESIMPULAN DAN SARAN}

\section{Kesimpulan}

Berdasarkan dari hasil penelitian yang telah dilakukan pada dosen Institut Keguruan dan Ilmu Pendidikan (IKIP) PGRI jember pada program studi pendidikan guru pendidikan anak usia dini didapatkan hasil analisis bahwa motivasi kerja, iklim kerja serta komitmen organisasi mempunyai pengaruh terhadap kinerja dosen. Dari pengukuran statistik yang ditarik kesimpulan sebagai berikut:

1. Motivasi Kerja memiliki pengaruh positif tidak signifkan terhadap Komitmen Organisasi dosen Pendidikan Anak Usia Dini IKIP PGRI Jember. Hasil tersebut tidak mendukung hipotesis pertama yang berbunyi Motivasi Kerja memiliki pengaruh positif yang signifikan terhadap Komitmen Organisasi. Sehingga jika IKIP PGRI Jember ingin meningkatkan Komitmen Organisasi bagi dosen hendaknya meningkatkan hal lain, selain dari Motivasi Kerja. Karena jika meningkatkan 
Motivasi Kerja dengan tujuan untuk meningkatkan Komitmen Organisasi maka dampak yang diperoleh dengan peningkatan Motivasi Kerja tersebut akan berdampak sangat kecil dalam peningkatan Komitmen Organisasi.

2. Iklim Organisaisi memiliki pengaruh positif signifkan terhadap Komitmen Organisasi pada lingkungan kerja dosen Pendidikan Anak Usia Dini IKIP PGRI Jember. Dengan diperolehnya hasil bahwa Iklim Organisasi berpengaruh signifikan terhadap Komitmen Organisasi maka hipotesis kedua dapat diterima. Maka dalam rencana untuk meningkatkan Komitmen Organisasi dapat dilakukan dengan meningkatkan Iklim Organisasi, dengan kata lain bahwa IKIP PGRI Jember harus mempunyai Ilim Organisasi yang bagus dan cocok bagi dosen terutama pada Pendidikan Guru Pendidikan Anak Usia Dini agar komitmen mereka terhadap organisasi juga meningkat.

3. Komitmen Organisaisi memiliki pengaruh positif signifkan terhadap Kinerja dosen Pendidikan Anak Usia Dini IKIP PGRI Jember. Hal ini menunjukkan semakin tinggi Komitmen Organisasi akan berdampak pada semakin meningkatnya Kinerja dosen IKIP PGRI Jember. Dengan diperolehnya hasil bahwa Komitmen Organisasi berpengaruh signifikan terhadap Kinerja maka hipotesis ketiga didukung oleh hipotesis tersebut yang bermakna bahwa jika Komitmen Organisasi meningkat maka Kinerja dosen Pendidikan Guru Pendidikan Anak Usia Dini IKIP PGRI Jember akan meningkat.

4. Motivasi Kerja secara langsung memiliki pengaruh positif tidak signifikan terhadap Kinerja dosen Pendidikan Anak Usia Dini IKIP PGRI Jember. hasil tersebut menunjukkan bahwa tidak adanya dukunga terhadap hipotesis keempat, maknanya jika menginginkan peningkatan pada Kinerja dosen Pendidikan Guru Pendidikan Anak Usia Dini IKIP PGRI Jember dengan cara meningkatkan Motivasi Kerja maka akan hanya berdampak sedikit terhadap peningkatan Kinerja.

5. Iklim Organisasi secara langsung memiliki pengaruh positif tidak signifkan terhadap Kinerja dosen Pendidikan Anak Usia Dini IKIP PGRI Jember. Hasil tersebut menunjukkan bahwa tidak didukungnya hipotesis kelima dengan adanya perhitungan. Artinya jika menginginkan Kinerja dosen Pendidikan Guru Pendidikan Anak Usia Dini IKIP PGRI Jember meningkat tidak bisa hanya dengan meningkatkan Iklim Organisasi. Karena Iklim Organisasi hanya berdampak cukup kecil terhadap 
Peningkatan Kinerja dosen Pendidikan Guru Pendidikan anak Usia Dini IKIP PGRI Jember.

6. Motivasi Kerja secara tidak langsung memiliki pengaruh positif tidak signifkan terhadap Kinerja dosen Pendidikan Anak Usia Dini IKIP PGRI Jember dengan Komitmen Organisasi sebagai variabel interveningnya. Hasil tersebut tidak mendukung terhadap hipotesis yang keenam yang menyatakan bahwa Motivasi Kerja berpengaruh signifikan terhadap Kinerja.

7. Iklim Organisasi secara tidak langsung memiliki pengaruh positif tidak signifkan terhadap Kinerja dosen Pendidikan Anak Usia Dini IKIP PGRI Jember dengan Komitmen Organisasi sebagai variabel intervening. Hasil tersebut tidak mendukung hipotesis ketujuh yang menyatakan bahwa Iklim Organisasi secara tidak langsung berpengaruh signifikan terhadap Kinerja dosen Pendidikan Guru Pendidikan Anak Usia Dini IKIP PGRI Jember. hal ini dapat diartikan bahwab peningkatan Iklim Organisasi tidak akan berdampak pula pada peningkatan Kinerja.

\section{Saran}

Berdasarkan dari hasil pembahasan dan kesimpulan yang telah ditetapkan di atas maka penulis dapat memberikan beberapa saran harapkan berguna bagi kepentingan praktis dan kepentingan penelitian selanjutnya.

\section{Bagi IKIP PGRI Jember}

a. IKIP PGRI Jember perlu memperhatikan Iklim Kerja untuk meningkatkan Komitmen Organisasi dan KInerja, karena pada analisis koefisien determinasi menunjukkan variabel Iklim Organisasi memiliki pengaruh terhadap Komitmen Organisasi dan Kinerja.

b. IKIP PGRI Jember perlu meningkatkan Motivasi Kerja karena dari hasil perhitungan, Motivasi Kerja mempunyai pengaruh tidak langsung atau menjadi variabel mediasi dalam peningkatan Kinerja dosen pada lingkungan kerja IKIP PGRI Jember.

c. IKIP PGRI Jember perlu meningkatkan Komitmen Orgnasasi sebungga dengan peningkatan Komitmen Organisasi maka Kinerja dosen pada lingkungan IKIP PGRI Jember juga akan meningkat.

2. Bagi peneliti selanjutnya 
a. Berdasarkan hasil penelitian terdapat beberapa saran yang dapat diberikan bagi peneliti selanjutnya. Peneliti selanjutnya diharap dapat menambah variabel variabel yang dapat meningkatkan kinerja.

Hasil analisis koefisien determinasi menunjukkan bahwa masih terdapat variabel lain yang harus diperhatikan dalam penelitian ini. Penelitian selanjutnya hendaknya menambahkan variabel lain yang dapat mempengaruhi Komitmen Organisais dan KInerja, karena masih banyak variabel lain yang dapat memengaruhi Komitmen Organisais

\section{DAFTAR RUJUKAN}

Adisty H. S. (2013). Hubungan antara persepsi karyawan terhadap gaya kepemimpinan partisipatif atasan dengan kinerja karyawan di RS Muji Rahayu Surabaya. Jurnal Psikologi Industri Dan Organisasi. 02 (1) 12-28.

Affandi, H. 2002. Pengaruh Iklim Organisasi Terhadap Kepuasan Kerja, Komitmen dan Kinerja Pegawai (Studi Kasus Pada Pegawai di Lingkungan Pemerintah Kota Semarang), Universitas Diponegoro.

Azhad, M Naely. Anwar, Nurul QOmariah. 2015. Manajemen Sumberdaya Manusia. Jember. Cahaya Ilmu.

Akbar, T.R. 2009. ' Pengaruh Iklim Organisasi Terhadap Kinerja Karyawan Pada PT. PLN (Persero) Wilayah Sumatera Utara Cabang Medan', Universitas Sumatera Utara.

Alavi, Hamid Reza dan Ramazan Jahandari, 2005, "The Organizational Climate Of Kerman Shahid Bahonar University”, Public Personnel Management, 34, No.3.

Al-Ahmadi, H., 2009, "Factors affecting performance of hospital nurses in riyadh region, Saudi Arabia", International Journal of Health Care Quality Assurance, 22 (1): 40-54.

Allen, Natalie J dan Meyer, John P. 1990. The Measurement and antecendents of affective, continuance and normative commitment to the organization, Journal of Occupational Psychology, 63 (1): 1 - 18.

Arifin Noor, Komaruddin. 2009 . Analisis pengaruh kepemimpinan, kapabilitas, komitmen terhadap kinerja anggota Satuan Komando Distrik Militer 0719 Jepara, Jurnal Dinamika Ekonomi \& Bisnis, 6 (2): 171 - 186. 
Bhenkhoff, B., (1997). Ignoring Commitment Is Costly: New Approaches Establish the Missing Link Between Commitment and Performance. Journal of Human Relations. 50 (6).

Benny, Roesly. 2012. Pengaruh Komunikasi Organisasi, Komitmen Organisasi,dan Iklim Organisais Terhadap Kinerja Guru di Lingkungan Sekolah Maitreyawira Batam.

Brown Steven, Tobias Huning. 2010. Intrinsic Motivation And Job Satisfaction:The Intervening Role Of Goal Rientation Proceedings of The Academy Of Organizational Culture. communications and conflict, Columbus State University. New Orleans. 15 (1): 1-5.

Chen, S.J., P.F. Lin, C.M. Lu, and C.W. Tsao, 2007, “The Moderation Effect of HR Strength on the Relationship Between Employee Commitment and Job Performance", Social Behavior and Personality 35 (8): 1121 - 1138.

Davis, K. \& Newstrom, J.W. 2001. Perilaku Organisasi Jilid 1. Jakarta: Erlangga.

Devito; Joseph, A. 1997 Komunikasi Antar Manusia (edisi kelima), Jakarta: Profesional Book.

Elisabeth Glorita Luisa Dos Santos Belo, I Gede Riana, Putu Saroyeni Piartrini. 2014. Pengaruh Kepuasan Kerja dan Motivasi Kerja Terhadap Komitmen Organisasional dan Kinerja Karyawan di Kantor Palang Merah Timor Leste. EJurnal Ekonomi dan Bisnis Universitas Udayana 3 (12).

English, Brian., Morrison, David., Chalon, Christhoper. 2010. Moderator effects of organizational tenure on the relationship between psychological climate and affective commitment, Journal of Management Development, 29 (4):394 - 408.

George, J.M. \& Jones, G.R. 2005. Understanding and managing organizational behavior (4th ed.). New Jersey: Upper Saddle River.

Ghozali, Imam. 2002. Aplikasi Analisis Multivariate Dengan Program SPSS. Edisi Kedua. Semarang : Badan Penerbit Universitas Diponogoro.

Ghozali, Imam. 2005. Aplikasi Analisis Multivariate dengan SPSS. Semarang: Badan Peberbit Universitas Diponegoro.

Ghozali, I. 2009. Aplikasi Analisis Multivariate dengan Program SPSS, Edisi Keempat. Semarang: Universitas Diponegoro.

Ghozali, Imam. 2013. Aplikasi Analisis Multivariate Dengan Program SPSS 21. Edisi Ketujuh. Universitas Diponegoro, Semarang.

Gomes, Faustino Cardosa. 2003. Manajemen Sumber Daya Manusia. Bandung: Remaja Rosdakarya. 
Henaldy. 2009. Pengaruh Iklim Organisasi Terhadap Kinerja Karyawan pada PT. Astra Internasional Tbk, Universitas Pajajaran Bandung.

Hasibuan, MSP, 2007. Manajemen Sumber Daya Manusia. Bumi Aksara. Jakarta.

Hasibuan, Malayu SP. 2006. Manajemen Personalia. Yogyakarta : BPFE.

House, R.J \& Shamir, B. 1993. Toward an Integration of Transformational, Charismatic and Visionary Theoris of Leadhership Perspectives and Research Directions. New York: academic Press.

Huselid, M.A (1995) The impact of human resource management pactice on turnover, productivity, and corporate financial performence. Academy of management journal, 38: 635-872.

Jatmiko, E,D. 2015. Pengaruh motivasi kerja dan komitmen organisasional terhadap kinerja karyawan (Studi pada karyawan kompartemen pabrik II PT. Petrokimia Gresik). Jurnal Administrasi Bisnis (JAB). 21, No. 1.

Jha, Sumi. 2011. Influence of psychological empowerment on affective, normative and continuance commitment: A study in the Indian IT industry, Journal of Indian Business Research, 3 (4): 263 - 282.

J.P Mayer N.J Allen and A.C Smith. 1993. Comitmen of organizations and occupation:extesion and test of a three-component conceptualization. Journal of Applied Psychology 78 (4): 538-551.

Juniantara, I Wayan. 2015. Pengaruh Motivasi dan Kepuasan Kerja terhadap Kinerja Karyawan Koperasi di Denpasar, Bali.

Keran, Kristuna Nugi. 2012. Pengaruh Motivasi Kerja, Kompetensi, dan Kompensasi Terhadap Kinerja Karyaan di Yayassan Bintang Timur Tangerang.

Kurniawati,O. 2011. Pengaruh Iklim Organisai Terhadap Komitmen Organisasi PT. Intech Anugrah Indonesia.

Lieke E. M. W. 2011. Pengeruh Kompensasi Kerja dan Motivasi Kerja Terhadap Komitmen Organisasi pada Organisasi Pendidikan.

Lussier, R. N. 2005. Human Relationship in Organizations: Application and skills building (6thed.) New York: McGraw-Hill/Irwin.

Maharjan, Sarita. 2012.Association between work motivation and job satisfaction of college teachers. Administrative and Management Review 24(2): 45-55.

Majorsy, Ursa. 2008. Kepuasan Kerja, Semangat Kerja dan Komitmen Organisasional pada Staf Pengajar Universitas Gunadarma. Journal. 
Mangkunegara, A.P. 2010. Manajemen Sumber Daya Manusia Perusahaan. Bandung: PT. Remaja Rosdakarya.

Maslow, A. H. (1994). Motivasi dan Kepribadian (Teori Motivasi dengan. Pendekatan Hierarki Kebutuhan Manusia). Jakarta: PT. Pustaka. Binaman Pressindo.

Mas'ud, Fuad. (2004). “Survai Diagnosis Organisasional (Konsep Dalam Aplikasi). Semarang: Badan Penerbit Universitas Dipenogoro.

Mathis, Jackson. (2000). “Manajemen Sumber Daya Manusia”. Jakarta: Salemba Empat.

Mowday, R.T., Porter,L.W., Steers, R.M. (1982). Employee Organization Linkages: The Phsychology of Comitmeen, Absenteeism, and Turnover. NewYork: Academic Press.

Muhammad, Arni. 2005. Komitmen Organisasi. Jakarta: PT. Bumi Aksara.

Naderi, Anari., Nahid. 2012. Teachers: emotional intelligence, job satisfaction, and organizational commitment, 24 (4):256 - 269.

Nawawi, H. 2007. Manajemen Sumber Daya Manusia untuk Bisnis yang Kompetitif. Yogyakarta: Gadjah Mada University Pres.

Nelson, A., Silvia. 2012. Affective commitment of generational cohorts of Brazilian nurses. Journal of Manpower, 33 (7): pp 804 - 821.

Palupi, SS. 2004. Hubungan Kepuasan Kerja dan Iklim Organisasi Terhadap Komitmen Organisasi.

Rivai, V. 2011. Manajemen Sumber Daya Manusia Untuk Perusahaan Dari Teori Ke Praktek. Jakarta: PT. Rajagrafindo Persada.

Robbins \& Coulter. 2012. Manajemen. Jakarta: Indeks.

Robbins, Stephen,P. 1994. Teori Organisasi Struktur Desain, dan Aplikasi. Jakarta: Arcan.

Robbins, Stephen, 2001. Perilaku Organisasi. (Organizatonal Behaviour) PT.Prehalindo, Jakarta.

Robbins., Stephen P \& Decenzon, David A. 2002. Human Resources Management. 7th ed. New York: Jhon Wiley \& Sons, Inc.

Robbins, Stephens P. 2003. Prilaku Organisasi, Edisi Kesepuluh, Prentice-Hall, Jakarta.

Roesly, Benny. 2012. Pengaruh Komunikasi Organisasi, Komitmen Organisasi,dan Iklim Organisais Terhadap Kinerja Guru di Lingkungan Sekolah Maitreyawira Batam. Tesis. 
Rowden W, Robert. 2000. The relationship between charismatic leadership behaviors and organizational commitment, Leadership \& Organization Development Journal, 21(1): $30-35$.

Santoso, Singgih. 2001. SPSS versi 10: Mengolah Data Statistik Secara Profesional. Jakarta: Elex Media Komputindo.

Sanusi, A. (2012). Pengaruh Motivasi Kerja dan Iklim Komunikasi Organisasi Terhadap Komitmen Keorganisasian Pegawai Arsip Nasional Republik Indonesia. Universitas Indonesia.

Shadur, Mark A; Kienzle Rene \& Rodwell John J., 1999, "The Relationship Between Organizational Climate and Employee Perceptions of Involvement”, Group and Organizational Management, 24 (4), December, pp.479-503.

Simamora, Henry. 1997. Manajemen Sumber Daya Manusia. Edisi kedua. Jakarta: STIE YKPN.

Simanjuntak, P. 2005. Manajemen dan Evaluasi Kinerja. Jakarta: Lembaga penerbit FE UI.

Simanjuntak, P. 2011. Manajemen dan Evaluasi Kinerja. Jakarta: Fakultas Ekonomi UI.

Sopiah. 2008. Perilaku Organisasi. Yogyakarta : CV. Andi Offset.

Stup, Richard E, 2006. Special Research Report: Humman Resource Management and Dairy Employee Organizational Commitment. The Pennsylvania State University.

Tania, A,. Sutanto, EM. 2013. Pengaruh motivasi dan kepuasan kerja terhadap koitmen organisasional karyawan PT. DAI KNIFE di Surabaya. Jurnal AGORA 1 (3): 3544.

Widjaja, H.A.W. 2002. Otonomi Daerah dan Daerah Otonom, Jakarta : PT. Raja Grafindo Persada.

Wirawan. 2007. Budaya dan Iklim Organisasi Teori Aplikasi dan Penelitian. Jakarta: Salemba Empat. 